\title{
The Grass Snake in Britain
}

\section{lan F. Spellerberg}

A questionnaire survey to investigate the grass snake's status in Britain showed that, while in some areas it was still abundant, in others it had declined and continued to do so, mainly through habitat destruction and collecting. The author concludes that, because of its special habitat requirements, this snake could easily become an endangered species in Britain, unlike the adder which can occupy many marginal habitats.

The harmless grass snake Natrix natrix helvetica is Britain's largest snake, often growing to $150 \mathrm{~cm}$ (59 in.) long. Olive-brown or dark green in colour, it usually has a yellow, orange or white collar behind the head. When disturbed it moves rapidly and noisily; if caught it will struggle violently and hiss. It is found throughout England and Wales up to about $55^{\circ} \mathrm{N}$., and there are a few reports from southern Scotland.

No long-term population or other ecological studies of this snake appear to have been completed, although there have been many incidental studies. This apparent lack of concern made me launch a preliminary investigation using questionnaires (despite the many disadvantages of this method). The questionnaire was in four sections: the first assessed the nature and duration of any grass snake studies; the second asked about changes in numbers and/or habitats; the third requested the reasons for changes and opinions on habitat requirements and predators; the final section was left for detailed information

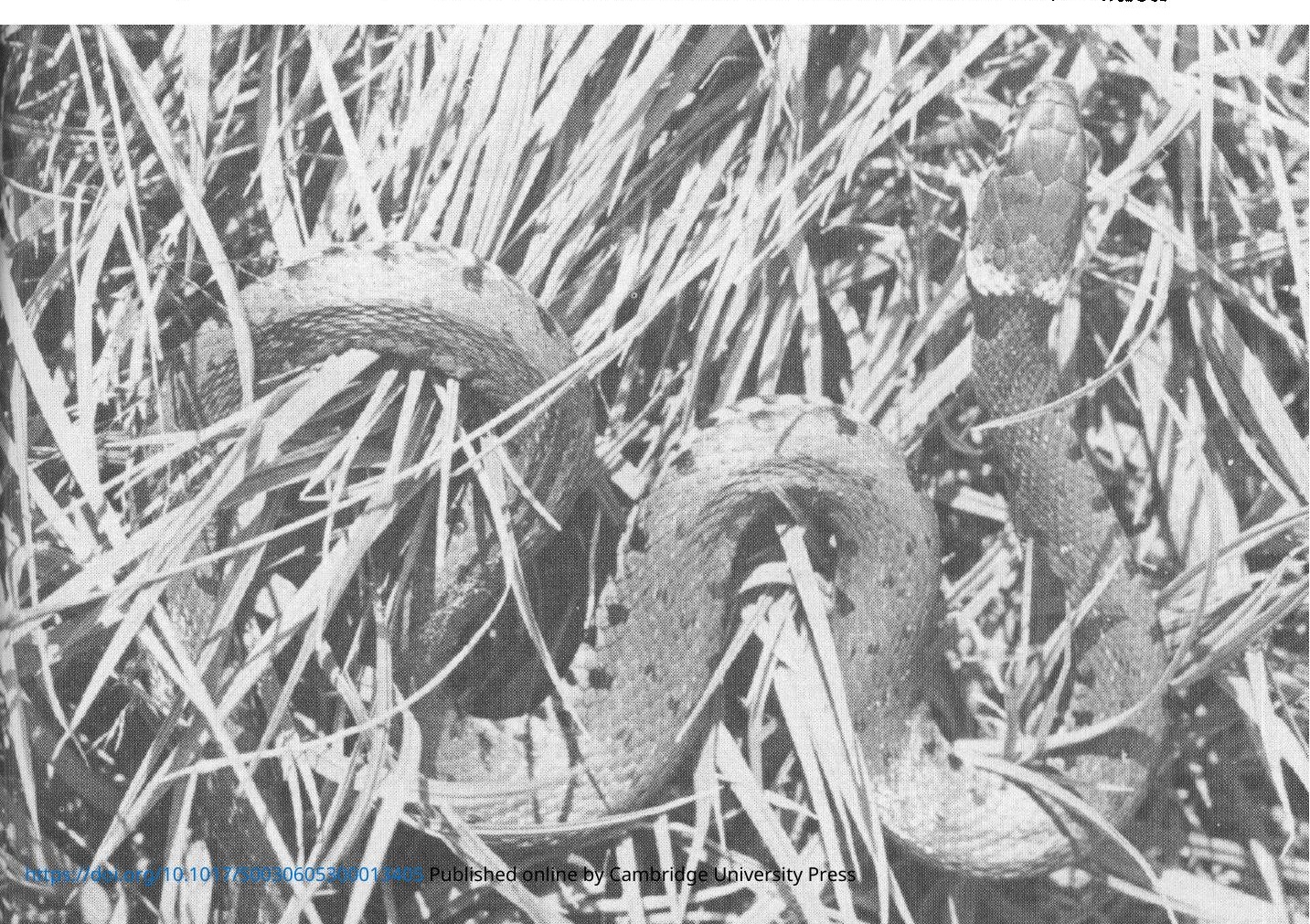


Table 1

\begin{tabular}{rcc} 
& \multicolumn{2}{c}{ Grass snakes } \\
& Replies & Percentage \\
Decreasing & 45 & $55 \cdot 6$ \\
Increasing & 11 & 13.5 \\
No change & 25 & $30 \cdot 8$ \\
Total & $\overline{81}$ &
\end{tabular}

Grass snake habitats

Replies Percentage

$44 \quad 55.6$

$6 \quad 7.6$

$29 \quad 36.7$

79

including empirical data. Although criticism of the questions ranged from comments like "too academic" to "non-specific", some objectives were fulfilled and many replied saying that they would start their own studies on this snake and keep detailed notes. Some of the information presented here is not empirical, nevertheless some valuable material has come out of the questionnaires. Special thanks are due to the BBC Living World programme and the many natural history societies who advertised the project.

Over a period of twelve months 600 questionnaires were distributed, half with return postage supplied. Returns numbered 143, of which 15 were discarded because of insufficient information, together with 28 letters giving additional information on grass snake biology. Many returns reported localities and population levels, sometimes with detailed maps, and this information has been passed to the Biological Records Centre at Monks Wood Experimental Station, Huntingdon. As publication of localities may simply show localities of observers I have not included this information but note that questionnaires were returned from over a wide area throughout England, Scotland, Wales and the Isle of Man.

One section of the questionnaire asked if grass snake populations and/or habitats had increased or decreased and requested the reasons and period if a change had been noted. The results, deriving from at least six years of observations for defined sites, are in Table 1.

Table 2

\section{Reasons for the Decline in Numbers}

Suggested reason

Drainage of ponds, land

Decline in amphibians

Building (houses)

"Tidying-up" and clearance of wilderness areas

Road construction

Dumping and spoiling of wilderness areas

Collecting

Afforestation

Fire

Unsuccessful incubation

Mining
Times suggested

22

21

20

14

11

9

8

6

5

3

2

121 
Table 3

Suggested Favoured Habitats

\section{Habitat Times suggested Percentage}

Wet meadows, streams in wilderness areas $\quad 55$

$53 \cdot 4$

Edges of woodland or forest, copse, spinney

Dense grassland-heathland with wet areas

$11 \cdot 7$

Large rural gardens

Gravel pits

Wooded roadsides, ditches

Railway cuttings

$\begin{array}{rr}12 & 11.7 \\ 10 & 9.7 \\ 5 & 4.9 \\ 4 & 3.9 \\ 2 & 1.9\end{array}$

Total 103

The greatest decrease in both numbers of snakes and in numbers of habitats occurred about the years 1963-1964 although other changes were reported over the period 1958-1974. The extent of the declines could not be quantified, but reasons for the decline in numbers were numerous; they are grouped in Table 2.

The overall impression was that grass snakes were generally diminishing in numbers (extent unknown) although they do remain plentiful in some areas. Dartmoor and North Hertfordshire were noted as two important areas where the species is now uncommon and decreasing. The number of young in all defined areas seem to have diminished, particularly over the last decade, and some reports mentioned a preponderance of males. Several detailed comments were received about the decline in frog populations and its relation to diminishing grass snake numbers, while others noted that if frog populations had declined some snake populations moved to areas where fish were abundant.

Population increases were attributed to improvement in weather conditions, active management of the snakes and their habitats, development of conservation areas, the increase in landscaped gardens, and to an increase in artificial incubation sites such as compost heaps, dried sewage and dung heaps. Happily there are several localities where this snake is still abundant, and in one area of woodland (less than $1 \mathrm{~km}$. sq.) three persons between them noted about 60 snakes over a period of about seven months.

\section{Habitats}

Table 3 classifies habitats thought to be suitable for grass snakes. Generally the best habitat was thought to be an undisturbed area where there was water or at least wet areas. Valleys and wet meadows with slow-moving streams were frequently noted, and plant species in these areas were reported to be Typha latifolia, Molinia and Carex spp. One novel site reported was the pits of Water Board meters.

\section{Predation}

The request for information on predation and mortality produced a large and often detailed response - see Table 4. 
Table 4

Suggested cause

Other snakes*

Heron Ardea cinerea*

Gulls

Buzzard Buteo buteo*

Sparrowhawk Accipter nisus

Osprey Pandion haliaetus

Marsh Harrier Circus aeruginosus*

Hobby Falco subbuteo

Kestrel $F$. timnunculus*

Owls*

Crows

Magpie Pica pica*

Mistle Thrush Turdus viscivorus

Hedgehog*

Shrews

Rats*

Fox*

Badger*

Stoat*

Weasel

Mink

Ferret

Domestic Cat*

Domestic Dog

Man and machines*

Collecting*

Predation and Mortality Factors

$\underset{(\%)}{S \text { Suggested by }}$

$1 \cdot 2$

$3 \cdot 8$

$1 \cdot 7$

$3 \cdot 8$

$2 \cdot 5$

0.8

$4 \cdot 2$

$1 \cdot 2$

$5 \cdot 6$

$4 \cdot 6$

$1 \cdot 7$

$1 \cdot 7$

0.8

$8 \cdot 6$

0.8

$1 \cdot 7$

$5 \cdot 6$

$6 \cdot 4$

$4 \cdot 6$

$2 \cdot 5$

$0 \cdot 8$

0.4

$3 \cdot 8$

$3 \cdot 3$

$23 \cdot 9$

3.9
Suggested by $(\%)$

(excluding man and machines)

* Recorded incident

$5 \cdot 2$

$2 \cdot 3$

$5 \cdot 2$

3.4

$1 \cdot 2$

5.8

1.7

$8 \cdot 1$

$6 \cdot 4$

$2 \cdot 3$

$2 \cdot 3$

$1 \cdot 2$

11.6

$1 \cdot 2$

$2 \cdot 3$

$8 \cdot 1$

8.7

$6 \cdot 4$

$3 \cdot 5$

1.2

0.6

$5 \cdot 2$

4.7

Several replies noted that the decrease in rabbit populations, caused by the virus disease myxomatosis, may have produced a greater predation on grass snakes by birds of prey. The impact of man and his machines was described in considerable detail and these reports included comments such as: "grass snake kicked to death"; "kill them all"; "killed in ignorance"; "I killed them all with pride". The lack of knowledge about grass snakes was noted; it appears that the police are often called in to deal with snakes, which, after being killed and taken back to the police station, are often identified as the harmless grass snake. Destruction of habitats and collecting by children were thought to be serious problems, and so also was commercial collecting. In at least one county between 200 and 300 grass snakes are collected each year to be sold in shops, and many replies indicated that commercial collecting was on a "gigantic scale". There were many reports of grass snakes dead on the roads (road kills) and this category may be more important than previously supposed.

\section{Food}

Although information on food was not requested, a considerable amount of data was received. Most thought that frogs (but usually not toads) together with fish, made up the greater part of this snake's diet. Small mammals such 
as short-tailed voles were known prey, and one report said that grass snakes were accused of taking the eggs and chicks from birds' nests.

\section{Discussion and Conclusions}

Although the grass snake may remain abundant in some areas, there is need for concern particularly in the absence of detailed population studies. Clearly this snake suffers from widespread habitat destruction, and although each mature female may produce between 16 and 37 eggs the mortality of the young could well be very high.

There appears to be an anomaly in the factors leading to the decline in numbers, for, while few considered collecting to be important (Table 2), a large number of people commented on the apparent extensive collecting for both commercial reasons and for vivaria. Detailed figures of this aspect are difficult to obtain, but it does call for investigation into the level of collecting and its impact on natural populations.

One further aspect which received little attention in the answers to the questionnaires was the role of insecticides, herbicides and pollution (although one reply noted that tractor-oil pollution can be a problem). This is one large blank in our knowledge of the reptiles, and more and more European herpetologists are looking to this aspect as a possible factor in the decline in reptile numbers.

It was encouraging to learn of a few recorded population increases, and of efforts to encourage this snake and other forms of indigenous wildlife to inhabit privately owned land. Not all gardeners, however, are keen to see snakes, and there is an interesting conflict between the interest in composting and the reluctance to allow grass snakes to use the compost for incubation. Composting was not the only practice which attracted snakes. Attempts to remove weeds from rocky areas by laying down tin or floor coverings has often resulted in the creation of excellent shelter for several of our native reptiles.

Many people expressed concern about the grass snake's survival, and some related how they had artificially incubated the eggs, later returning the young to the countryside. Others described attempts to maintain vivaria in the hope of allowing a better breeding success. Such activities have some merit, but the import into England of European forms must be condemned. It appears that imports are often released, which could lead to the interbreeding of what are probably two distinct forms. The British form may be unique,

ROAD KILL IN THE NEW FOREST Ian F. Spellerberg

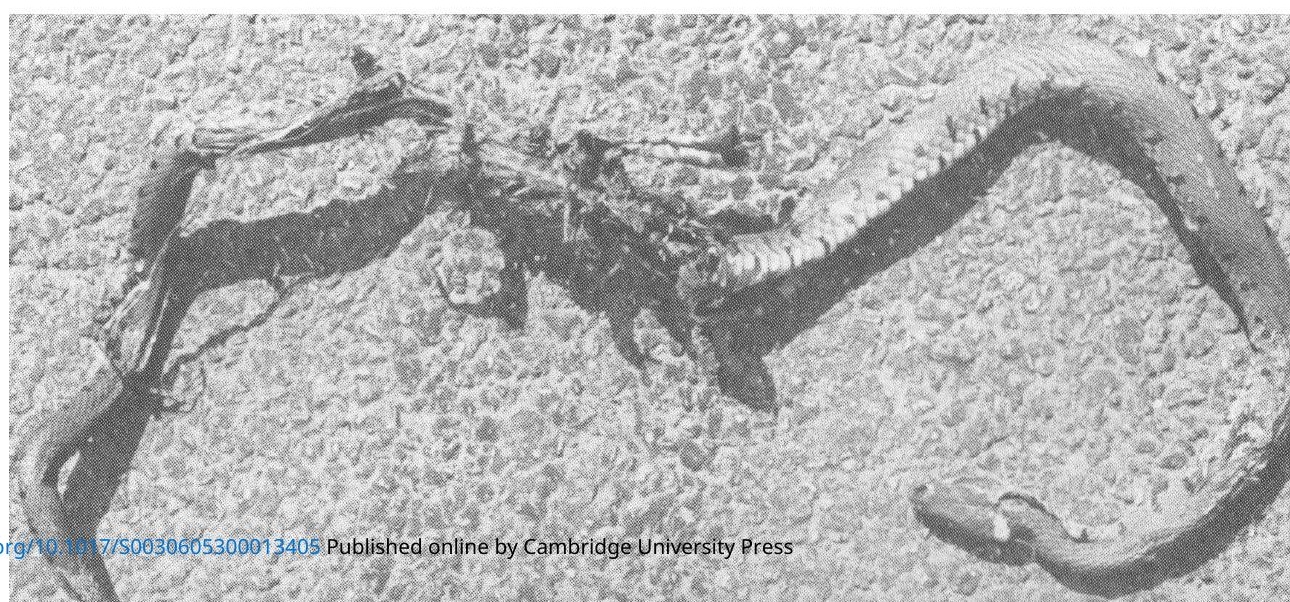


and any activity which might lead to its physiological or genetic alteration should be actively prevented, as should the release of any continental and North African species which are known to have been released or at least to have escaped from captivity.

The grass snake's ecological requirements have yet to be examined in detail, but it is known that its distribution range is to some extent limited by a need for warm wet areas, a type of habitat that is easily destroyed. The grass snake could easily become an endangered species, whereas the adder, which can successfully occupy many marginal habitats, has a far greater chance of remaining widespread and plentiful. Campaigns such as the British Waterfowl Association's "Save the Village Pond" could do much to preserve suitable areas for the grass snake as well as for many other species of wildlife.

Dr Spellerberg is a lecturer in the Biology Department, Southampton University.

\section{Smuggled \\ Pangolins}

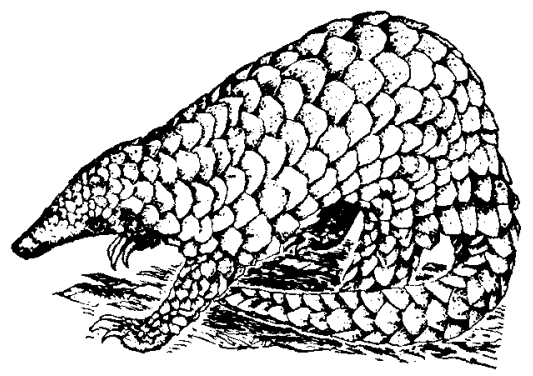

Ken Scriven, FPS Consultant in Malaysia, writes:

A smuggler was recently caught at the Malaysia-Singapore frontier trying to export 41 pangolin skins into Singapore - the scaly anteater or pangolin is a protected animal in Malaysia. The smuggler was fined M $\$ 4100$ or four months' jail and his Mercedes-Benz confiscated. From Singapore the skins would probably have been exported to Hong Kong or China where the scales are used as a medicament to cure the sick and lovelorn, or they may have been destined for the American market where a leading leather manufacturer currently offers Malaysian anteater boots at US\$300 a pair!

For many years pangolin skins have been exported in large numbers to Hong Kong and China, mainly, it is believed, from Indonesia; a local expert calculated some years ago that exports to China amounted to well over 60 tons over a 7 -year period. By simple arithmetic, based on the average size of pangolins, this represented more than 50,000 animals. In Malaysia the pangolin is now totally protected and is recognised as an endangered species under the new international convention on trade in endangered species.

\section{Captive Gharial Breeding}

A sanctuary for the gharial Gavialis gangeticus, India's highly endangered crocodile, was established in Orissa in April this year, at Salkosia, on the Mahamadi river, with FAO/UNDP assistance. Dr Robert Bustard, FAO consultant who is advising the Indian Government on crocodile conservation, collected eggs from tribal people who had dug them up to eat; by the end of June forty-two had hatched and are being captive-reared in Dr Bustard's care. Without captive breeding and well guarded sanctuaries the gharial is quite certain to become extinct. 